\title{
THE IMPACT OF IFRS 9 IMPAIRMENT CALCULATION ON EUROPEAN BANKS' MARKET RATING
}

\author{
Tamás Szücs - Gábor Márkus
}

\begin{abstract}
Following the financial crisis, the set of rules governing international accounting needed to be reshaped so that financial disturbance could be predicted in future. As of 1 January 2018, IFRS 9 specified how financial instruments should classify and measure and how impairment should be recognised. In this paper our objective has been to identify IFRS 9 financial statement figures significantly affecting the market rate of financial institutions. We have found that the market was more affected by the volume of financial instruments and impairments than by their evolution in time.
\end{abstract}

JEL codes: G21, M41

Keywords: IFRS 9, financial instruments, impairment, share prices

\section{INTRODUCTION}

Global financial markets have been developing significantly since the 1970s particularly over the last decade. As a result of the globalisation of the financial system, the settlement of individual financial transactions cannot be narrowed down to the accounting standards of any one given country. Traditional transactions have been supplemented with new kinds of financial instruments widely used not only by banks but also by other businesses for different purposes. The valuation criteria of the relevant accounting standards cannot identify the market value of a business implicitly. Traditional accounting records set the value of different assets based on their past countervalue paid on purchase. The application of past (purchase) price has been criticised by many on many occasions, summary papers have also been published on it (Georgiou-Jack, 2011). The methodology of fair valuation has been developed to solve that problem. Fair value, in practice, prefers the present value of assets based on the prices of an available, regulated,

1 Tamás Szücs, assistant professor, University of Pécs. E-mail: szucs.tamas@ktk.pte.hu. Gábor Márkus, assistant professor, University of Pécs. E-mail: markus.gabor@ktk.pte.hu. 
and liquid market. There are enough buyers and sellers in the liquid market, so pricing can be effective.

A business can face several risks during its operation that have a heavy impact on its future. Risks can be economic, financial, political, etc. Financial risks can be currency related or interest related. Effective risk management requires that the value of financial risks and the resulting benefits and risks be known.

The bodies establishing accounting standards responded to the financial crisis hitting the world in the second half of 2008. The International Accounting Standards Board (IASB) started to design a new standard already in November 2008 to be adapted to solve the problems generated by economic and financial crises. In addition, devising a more effective methodology for prevention was among the objectives too. The IFRS 9 standard set out the rules for three areas:

1) a simpler, more effective classification and valuation mechanism of financial instruments,

2) impairment allowance as the most important means of prevention, and

3) hedging transactions.

\section{IAS 39 CLASSIFICATION AND IMPAIRMENT OF FINANCIAL INSTRUMENTS}

By the IAS 39 standard effective until 31 December 2017, financial instruments had been classified into four groups.

1) Held-for-trading financial assets and liabilities - changes of their fair value had to be recognised directly in the profit or loss, so those value changes had a direct impact of the profitability of a business.

2) Available-for-sale financial assets are the second group of financial instruments at fair value. In that case their held-for-trading nature is not dominant, but their holders do not wish to hold them until maturity or they have no maturity. According to the valuation rules of the standard, at the initial valuation the difference between their purchase value and fair value must be recognised in the profit, while later on the valuation must be posted separately under equity as revaluation reserves (or by another name: other comprehensive income OCI). In that way the resulting appreciation will not directly modify the profit or loss of the given year but the net asset value (equity) of an enterprise. Naturally, the OCI mentioned will not be part of equity for ever, by the IAS 39 standard it must be transferred to profits if an asset is derecognised (for instance, sold). If the value of available-for-sale financial assets suffer a 
negative change that is fixed in the standard and can be proved objectively, the loss must be posted in the profit as impairment.

3) The third category consists of financial instruments held till maturity. They are assets having fixed maturity and fixed or identifiable payments a business intends to hold till maturity.

4) The fourth group includes own generated receivables. They are receivables generated at the sale of the products and services of a business or on granting a loan. In that case, short term sale is not the goal of the business. Both instruments held until maturity and own generated receivables must be valued at amortised cost.

At the beginning of the financial crisis (October 2008), to mitigate the effects, the IASB allowed non-derivative held-for-trading and available-for-sale financial instruments to be reclassified. Fiechter's (2011) analysis of a group of European banks showed that a third of the organisations involved used the opportunity. The impact of reclassification on profits modified the profitability of the banks positively. This resulted in posting profits closer to the principle of prudency, which was well received by analysts. Lim et al (2012) studied the impact of the 2008 reclassifications on analysts' forecastingabilities. They found the accuracy of forecasts had significantly declined, but the effects related to the given year only. Studying 122 European banks Zhan (2013) examined the direction of the changes induced by reclassification in the liquidity of a given bank. In the case of the banks using reclassification it had a negative effect on liquidity. Ozili (2019) analysed in a paper the extent to which reclassification into the above categories allowed by the IAS 39 standard could be used for profit smoothing. The author's presumption was that the banks used impairment to smooth their profits. In the analysis he found that in the period 2005-2013 European banks did not use impairment to level out incomes, further, posting requirements of IAS 39 significantly improved the estimation of credit losses and informativity of financial statements. Paananen, Renders and Shima (2011) examined if the reclassification by IAS 39 had any consequence on the capital markets. The authors believe there were two main drivers for reclassification: solvency and exposure to the financial markets. The former was used by banks having close to minimum capital adequacy ratio while the latter increased the probability of reclassification for players with higher fair value exposure.

The IAS 39 standard followed the traditional logic of accountancy, i.e. you could only record an event if it could be supported by proper proof or records. The impairment model applied in the standard (,incurred loss model”) allowed for recognition of incurred impairment of a given financial instrument based on strictly objective proof. In effect, it was a „tax-office-friendly” solution, since it presented events already having occurred and properly documented to inform 
investors. The 2008 crisis shed light on its dark side though. Impairment only allowed the recognition of loss already incurred, so - if the model was applied credit losses on financial assets could only be recognised subsequently, i.e. they appeared in the books too late for those affected.

It should be noted that the compilers of financial statements could not consider the potential effects of future events occurring after balance sheet date even if their occurrence were highly probable. In the model of incurred loss, a bank management could only post impairments before a loss-making credit event if its probability of default (PD) was close to $100 \%$. To calculate the actual value of expected loss, the initial effective interest rate must be used as discount rate. As Figure 1 illustrates, incurred loss is the lowest value limit out of the continuity of the potential estimates of anticipated losses. The logic of the incurred loss model is contrary to regulatory requirements (Basel I-III). Banks had much more opportunity for income smoothing under IAS 39 than by applying forward looking loss management according to Basel rules (Gerhardt-Novotny-Farkas, 2011).

\section{Figure 1}

\section{Expected losses}

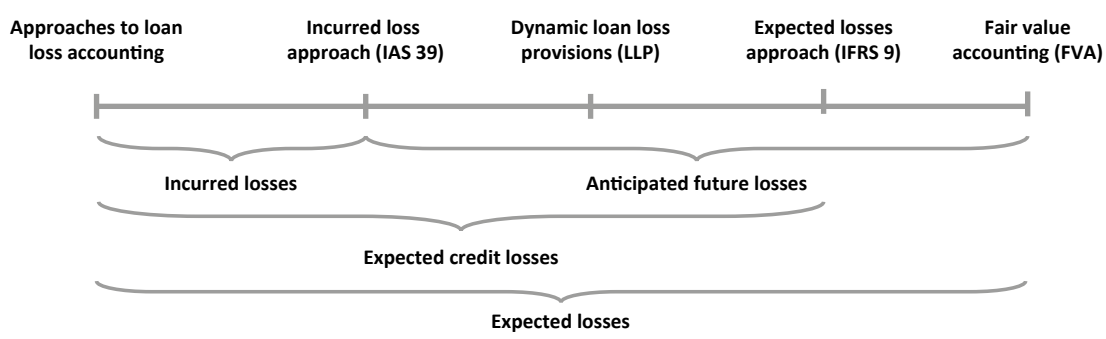

Source: own design based on Gebhardt-Novotny-Farkas (2011)

The main criticism against IAS 39 was its complexity and difficult application causing serious damage to the transparency of financial statements (Fiechter, 2011; Paananen et al., 2012, Laux-Lenz, 2010; Laux, 2012). Gerhardt-Novotny-Farkas (2011) and O'Hanlon (2013) also pointed out that valuation on balance sheet date did not allow a fast response to future losses leading to late realisation in that way. The incurred loss model contributed to procyclicality by „urging” banks to set aside higher impairment provisions during a recession. (El Sood, 2012; BeattyLiao, 2011) 


\section{IFRS 9}

The new IFRS 9 fundamentally rearranged earlier finance rules related to the recognition of financial instruments. Several factors motivated the design of the new standard. Its objectives were manifold. On the one hand, it aimed to provide an approximation of global accounting principles to the different accounting systems, which is still ongoing today, and on the other hand, to simplify the settlement of financial instruments as well as to give a reassuring answer to the growing criticism of IAS 39 during the crisis. As part of a comprehensive, very ambitious project, IFRS 9 rewrote IAS 39 in several phases: classification categories have changed, therefore their valuation has changed as well, in addition, the logic of calculating impairment has changed as well.

\subsection{IFRS 9 standard classification}

A more expressed change occurred in the classification of financial instruments although it was of less importance from a professional point of view. IAS 39 classified financial instruments subject to the objective they were held for as their "talking” names also expressed. On the other hand, IFRS 9 focused on a different method of valuation also reflected in the names of its categories. Figure 1 is a summary of the process.

Table 1

Changes in classification of financial instruments

\begin{tabular}{lccc}
\hline IFRS9 & $\begin{array}{c}\text { On profit } \\
(F V T P L)\end{array}$ & $\begin{array}{c}\text { On OCI } \\
(F V T O C I)\end{array}$ & $\begin{array}{c}\text { Recognised } \\
\text { at amortised cost } \\
\text { IAS39 }\end{array}$ \\
\hline $\begin{array}{l}\text { Relognised for fair value } \\
\text { Own generated }\end{array}$ & $\mathrm{x}$ & $\mathrm{x}$ \\
$\begin{array}{l}\text { Held till maturity } \\
\text { (HTM) assets }\end{array}$ & Terminated, needs to be reclassified \\
$\begin{array}{l}\text { Held till maturity } \\
\text { (HTM) liabilities }\end{array}$ & & & $\mathrm{x}$ \\
Available-for-sale $(A F S)$ & $\mathrm{x}$ & $\mathrm{x}$ & $\mathrm{x}$ \\
\hline
\end{tabular}

Source: own design

By IFRS 9 the classification categories „available-for-sale” and „held till maturity” used by IAS 39 were cancelled (including the rules on the consequence of sale 
before maturity). Under the new standard, the following valuation categories may be applied:

1) Financial instruments valued at amortised cost (AC): the business strives to collect cash flow (principal and interest).

2) Financial instruments at fair value on other comprehensible income (FVTOCI): a sales target might be there side by side with realising cash flow.

3) Financial instruments at fair value on profit and loss (FVTPL): „others”; i.e. an instrument is to be posted there unless it is in the category of amortised cost or fair value on other comprehensible income.

At first sight, the available-for-sale financial instruments by the old standard and financial instruments at fair value on other comprehensible income by the new one might seem quite similar. If, however, the classification criteria of the standards are compared, the decision is not so unambiguous. IFRS 9 strictly requires the realisation of contractual cash flow (principal and interest), while IAS 39 only regulated ability and intention, so businesses had to reclassify a part of availablefor-sale financial instruments into the category of valued at amortised cost when reclassifying on 1 January 2018.

\subsection{Impairment by IFRS 9}

The new IFRS 9 standard requires banks to set up a wide information base to identify credit losses. Financial institutions compiling statements must summarise information arising out of past experience, current conditions and reasonably expected future predictions to measure credit losses. By the new set of rules the identification of impairment is not fixed to the occurrence of an unfavourable credit event but you must monitor the evolution of expected credit loss (ECL), which - unlike IAS 39 regulations - is a preventive measure allowing to spot any problems in time.

The new standards require different measures in relation to loans depending on the types of risks identified. Accordingly, disbursed loans can be categorised into three different „baskets” subject to the risk of default:

Category 1: with respect to assets booked at amortised cost, impairment allowance must be made for short term expected losses, the amount of which cannot be nil. The old IAS 39 standard did not include such a requirement.

Category 2: for instruments where credit risk increases significantly, full lifetime expected credit losses are recognised at individual or portfolio level. IAS 39 did not include such a requirement. 
Category 3: certain financial instruments are already impaired at their origin on recognition (purchased as such), i.e. they are non-performing financial instruments. For non-performing financial instruments, impairment for the remaining term is established on their book value (net value).

Table 2

Management of expected credit losses

\begin{tabular}{lcc}
\hline IFRS 9 category & Credit rating & $\begin{array}{c}\text { Expected credit loss } \\
\text { (ECL) }\end{array}$ \\
\hline Category 1 & Performing loan & 12-month loss \\
Category 2 & Underperforming loan & Full lifetime expected loss \\
Category 3 & $\begin{array}{c}\text { Non-performing loan, } \\
\text { impaired }\end{array}$ & \\
\hline
\end{tabular}

Source: own design based on IFRS 9

Impairment allowance is based on the evolution of the credit risk (IFRS 9):

- If the credit risk of a given financial instrument has not increased significantly since its original recognition, you must reckon with 12-month expected credit loss.

- If the credit risk of a given financial instrument has increased significantly since its origin or compared to the previous rating period, full lifetime credit loss must be used to identify impairment.

Under normal operations, loans disbursed are first in category 1. A loan will be reclassified if the client's credit rating deteriorates in line with pre-defined indicators and - according to a forecasting system set up by the bank - there are signs to indicate that the probability of a negative loan event occurring increases. Thus, by IFRS 9, the loan will be reclassified into category 2 as underperforming. Loans causing the bank actual losses are to be classified into category 3.

As the standard was implemented on 1 January 2018, businesses had to review their financial instruments according to the new categories, while impairment values had to be set to the new values based on the new model. All that had an impact on banks' balance sheet total and the assessment of the quality of financial assets and liabilities. Since the new rules of impairment are stricter than earlier, the industry predicted an increase of impairments and a reduction of balance sheet totals. 
There is not much literature analysing the impact of how impairment is established by a bank on its stock exchange rate. In their paper Beaver et al. (1989) presented a model analysing the relationship between the market and book values of a bank's ordinary shares to see how much impact the supplementary information to financial statements had on the difference of the two values. By modelling, they found the supplementary information on a bank's loan portfolio exerted a significant impact. Their findings show a negative relationship between the change of non-performing loans and share prices. In their analysis, credit loss provisioning is a positive message for market players, which can be interpreted as the sign of prudent management. Research by Achmed et al. (1999) was directed to find a relationship between capital and income management and credit loss provisioning. According to the analysis of 113 banks, impairment allowance had an adverse effect on future profitability as well as on current stock exchange rates. Studies by Onali and Ginesti (2015) wanted to discover if changing the international accounting standards on impairment was the proper „cure” to recover investors' confidence. The authors believe impairment allowance in line with the new IFRS 9 rules can induce changes in share prices for several reasons. They state it corrects the banks' opportunities of timing to recognise the impairment of financial instruments. Market prices may respond well if investors believe the impairments in the statements were recognised in time, which improves the reliability of the statement regarding the credit portfolio of the bank in question. According to an analysis made in 17 countries involving 137 banks from July 2009 to 2014 , international investors did not realise the importance of impairment allowance on expected losses.

In their paper Covas and Nelson (2018) examined what banking decisions would have been made in the crisis period if the expected credit loss model had been applied. They modelled the period 2005 to 2013, and found the use of the expected loss model provided a more cyclical estimation than the actual loss model. Based on their findings, you could have expected a deeper crisis, as the lending activity of banks would have declined by another $9 \%$. In line with the new rules, expected losses should have been provisioned for the initial loan amount for all loans, so banks would have been unwilling to grant loans to risky clients, since they should have recognised an immediate loss.

Lu and Nikolaev (2019) studied the economic impact of the impairment provisions identified by the new standard. They think impairment on expected losses as against impairment on incurred losses is much more informative and its behaviour is anti-cyclical. Their findings show that using the model on expected impairment may result in high capital costs in future, while expected impairment set too low may distort a bank's decisions on lending, funding and dividends. 
Wheeler (2019) has found a stronger connection between expected losses not provisioned and the evolution of stock exchange rates in the case of large banks. As a result of the wider information base of large banks, investors can understand the extent of expected losses quantified for full life better. Wheeler thinks investors incorporate the information on expected losses into share prices although he could not make an exact estimation on its extent. The transparency of banks may increase if decision makers incorporate their own private information the investors cannot obtain from other sources into their estimation of expected losses.

In their paper Cantrell-McInnis-Yust (2014) examined if the fair value of loans or their purchase cost provide more useful information regarding the impairment of credits. They underline in their analysis that credit losses recognised by the banking industry may lead to severe far reaching consequences. They found the net purchase price of loans can be used for the estimation of their future impairment better than their fair value.

In their paper Kund and Rugilo (2019) analysed the impact of the expected credit loss model by IFRS 9 on financial stability. When the regulation shifted from the model of incurred losses (IAS 39), it launched two forces in opposite directions. The authors believe its net impact continues to be ambiguous. While the timely recognition of losses mitigates procyclical effects and improves financial stability, it weakens capital adequacy, which potentially offsets the advantage of the former. The authors underline the importance of the „cliff effect”. As you can see on Figure 2, IAS 39 only allowed the write-off of large losses at the end of the life of a loan all of a sudden when the loan was placed in category 3. On the contrary, IFRS 9 allows it to be recognised in stages, more gradually.

\section{Figure 2}

\section{"Cliff effect"}

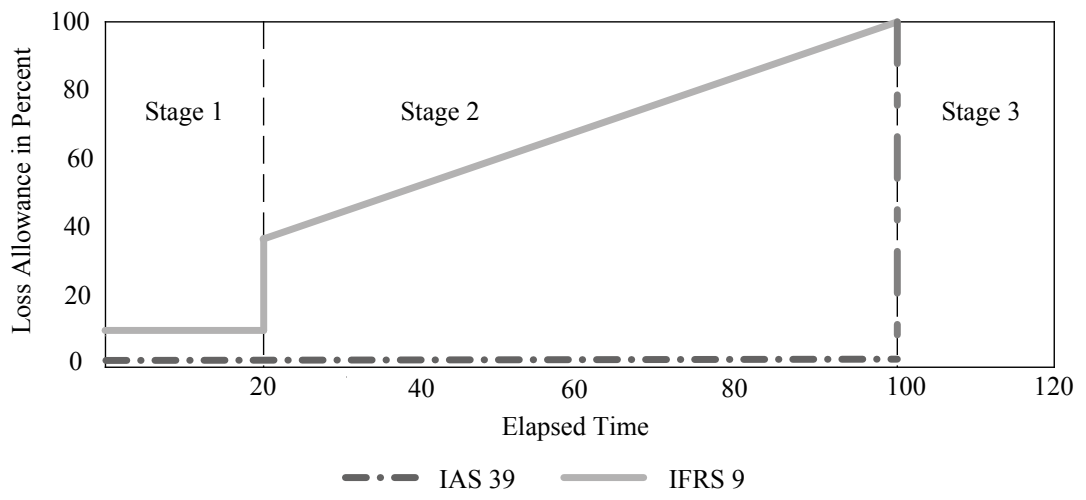

Source: Kund and Rugilo (2019) 
According to Kund and Rugilo, the implementation of IFRS 9 mitigated the severity of the „cliff effect” successfully by provisioning for expected credit losses in advance. As a result, less safe loans carry higher costs initially, which may lead to a shock in the credit offer of the banks and may prevent bank managers to find secondary markets for such loans. Thus, the quality of the tool becomes more important under the new accounting standard.

\section{HYPOTHESES}

While switching from IAS 39 to IFRS 9 the changes in the rules had effects in three directions, so our hypotheses also focus on them. The first mechanism aimed at changing the classification of financial instruments. Its main target group was the earlier „available-for-sale” category now assessed on OCI. While earlier the category functioned as „other”, i.e. it had instruments that could not be classified elsewhere, after the change of regulations the financial institutions had to execute a more careful examination of those assets. They had to be reclassified into the group best corresponding to the purpose they had been held for. Other minor changes not to be described in detail now also meant that financial institutions had to change the classification of their instruments materially. Our first hypothesis is built on that fact:

H1: Changing the structure of financial instruments in the balance sheet had a material effect on the evolution of the market rate of financial institutions.

The other main direction of the modification of the rules was a basic change in the logic of recognising impairment. An unusual new approach appeared in accounting by the regulation deducing impairment from future events as opposed to impairment based on the past. All trade expectations said the switch from realised credit loss (impairment) to expected credit loss (ECL) would result in an increase in the volume of impairments. Our second hypothesis is linked to that:

H2: Changing the methodology of recognising impairment had a material impact on the evolution of the market rate of financial institutions.

Changes in the recognition of impairment as discussed above have an indirect effect on the balance sheet total of financial institutions: it is expected to show a trend of reduction according to preliminary expectations. The change is probably quite small compared to the size of the financial institutions involved. It is customary to incorporate a factor related to the size of the business examined 
as a control factor, and this is now combined with the fact that the change of the regulation indirectly leads to a change in balance sheet total.

H3: Changes in balance sheet total had a material effect on the evolution of the market rate of financial institutions.

Our last hypothesis focuses on the availability of information. There are no rules in the standard fixing the disclosure of figures related to the shift to IFRS 9 to an actual date in time. Financial institutions were free to choose one of three options.

1) they could first disclose their new figures by IFRS 9 as part of the financial statement of 2017; or

2) they could disclose them as part of the interim statement compiled in Q1 2018; or

3) they could devote a separate document to the changes of IFRS 9 independent from their statements.

The third version, i.e. a separate document had to be published some time between the year-end and the quarterly statement. Our fourth hypothesis is related to that:

H4: The circumstance of when and in what format a financial institution disclosed IFRS 9-related information had a material effect on the evolution of its market rate.

We examine using the above four hypotheses the impact IFRS 9 exerted on the evolution of the market rate of financial institutions. We intend to emphasise, both here and later in the part on methodology, that our objective is to identify the accounting data and data groups that had a significant impact on market rates. We do not aim to explain the evolution of stock exchange rates with the help of actual regression parameters.

\subsection{Database}

Our research has been based on the IFRS 9 statements of 91 financial institutions floated on European stock exchanges and on their daily closing rates. The stock exchange figures have been collected from the Yahoo Finance web interface. 
Table 3

Distribution of the banks in the sample by countries

\begin{tabular}{lc}
\hline Country & No of banks \\
\hline Austria & 5 \\
Belgium & 3 \\
Denmark & 3 \\
Finland & 2 \\
France & 4 \\
Germany & 3 \\
Great Britain & 6 \\
Greece & 5 \\
Ireland & 4 \\
Italy & 12 \\
Latvia & 1 \\
Netherlands & 5 \\
Norway & 2 \\
Poland & 5 \\
Romania & 1 \\
Russia & 5 \\
Spain & 5 \\
Sweden & 7 \\
Switzerland & 6 \\
Turkey & 7 \\
Total & $\mathbf{9 1}$ \\
\hline
\end{tabular}

Source: own compilation

Two types of financial statements by IFRS were used. One consisted of the statements compiled on balance sheet date on 31 December 2017, the other included the interim financial reports of financial institutions. In every case, the statements were compiled in line with the effective set of regulations at the time, i.e. the statements closing year 2017 reflected the old IAS 39 schedule while the interim reports published in 2018 were compiled according to the new IFRS 9 standard.

Since the new set of rules allowed, financial institutions could decide on the form they applied to disclose the figures of shifting to IFRS 9. It could be published either as part of the 2017 statement or in a separate information document. ${ }^{2}$

2 It should be noted that the standard offerred the option by which a financial institution could neglect disclosure of detailed figures. Fortunately, really few banks used it, but the ones that did had to be omitted from our analysis - that is how the sample of 91 enterprises had come into being. 
The following figures were collected from the reports of all financial institutions (there is detailed explanation in the Annexes):

Table 4

Finance figures

\begin{tabular}{|c|c|}
\hline Name & Remark \\
\hline \multicolumn{2}{|c|}{ Balance sheet total } \\
\hline FVTPL & $\begin{array}{l}\text { Fair value through profit and loss (under previous standard: } \\
\text { financial instruments held for trading) }\end{array}$ \\
\hline FVOCI & $\begin{array}{l}\text { Fair value through other comprehensive income (under } \\
\text { previous standard: financial instruments available-for-sale) }\end{array}$ \\
\hline $\mathrm{AC}$ & Financial instruments at amortised cost \\
\hline Impairment & Impairment calculated by the old scheme (IAS 39) \\
\hline ECL & $\begin{array}{l}\text { Expected credit loss; impairment calculated } \\
\text { by the new standard (IFRS 9) }\end{array}$ \\
\hline
\end{tabular}

Source: own design

Descriptive statistics of the variables analysed are in the Annexes. Financial figures were collected for three dates:

1) balance sheet date as of 31 December 2017, identified under the old (IAS 39) standard;

2) balance sheet date as of 1 January 2018, which was a review of the 31 December figures under the new rules of IFRS 9 (it could be a part of the report or a separate publication), and

3) 31 March 2018; i.e. interim figures disclosed after the end of Q1 2018.

The stock exchange rate figures were adjusted to the publication of the financial statements. Accordingly, the 2017 statement was published in February-March 2018; this is public and can be traced back for all financial institutions. The interim reports for Q1 2018 were published in April-May 2018; again, the data are available as above. We collected exchange rate figures adjusted to the dates of publication so that the average of the closing rates of 5-5 days before and after the publication was used. 


\subsection{Model}

Figure 3 illustrates the process of model building in $3+1$ steps. The Figure includes the first three steps, step 4 - introduction of the time variable - would make it incomprehensible, so it is explained in the main text. For easier understanding, details are added in the Annex including all codes.

In our study we examined the changes in stock exchange rates of financial institutions on 3 dates:

1) disclosure of the 2017 financial statement;

2) disclosure of the Q1 2018 report;

3) dor the whole period from the publication of the 2017 report till that of the Q1 2018 report.

In every case the exact date of disclosure is known, and we used the average of the closing rates of 5-5 trading days before and after the disclosure. Although the selection of the 5-5 period is arbitrary, two considerations are worth noting. We could incorporate in our analysis both the immediate effect (+/- 5 days) and the effect of the quarter year (90+ days) between the year-end and the quarterly report. Longer periods by other authors (typically 30 to 180 days) are used in studies analysing the time course of an effect.

Figure 3

Process of model building

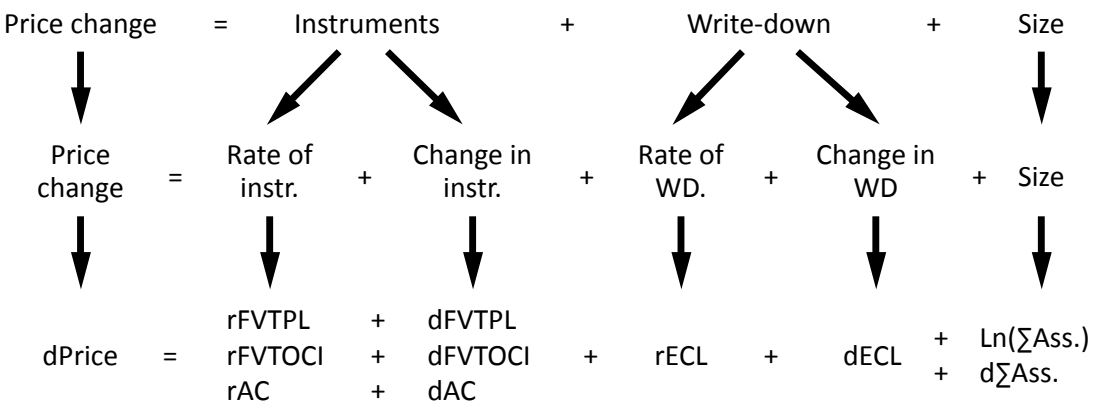

Source: own design

We intended to rely on 3 effects to explain the changes in stock exchange rates:

1) the internal structure of financial instruments,

2) the impairment recognised on the instruments,

3) the size of financial institutions. 
In a separate step we supplemented the analysis with the disclosure dates of the application of the new IFRS 9 standards.

We broke down the model to variables in the following steps (see detailed description in the Annexes):

1) First, we broke down the instruments and impairment to their ratios compared to balance sheet total (marked by prefix "r") and to their percentage change compared to the amount of the preceding period (marked by prefix " $\mathrm{d}$ ").

2) For size, we calculated the natural logarithm of balance sheet total as of 31.12.2017 and, in the next period, the percentage change of balance sheet total compared to the amount in the preceding period.

3) In the next step, in line with the regulation, the instruments were broken down further to 3 types (FVTPL, FVTOCI and AC).

4) Last, we broke down each variable by dates, i.e. whether they were generated in accordance with the old rule (31.12.2017) or the new one (31.03.2018).

We analysed the data by means of SPSS using OLS regression. To devise the regression, we considered the explanatory variables using either the „enter” or the „backward” method. The „enter” method was used when explanatory variables were fully considered. We also turned to the „backward” method because it proved to be fast and efficient when we examined which explanatory variables could be omitted from the model to improve its explanatory power.

Thanks to the „backward” method, SPSS can analyse a high number of models in every case, of which we selected the ones that were:

- Significant at 10\% significance level based on variance analysis (ANOVA), and

- their adjusted value $\mathrm{R}^{2}$ was the highest of the models generated.

As a result of the above two selection criteria, some models were also selected where some variables at $10 \%$ significance level did not exert a significant impact. Stricter statistical conditions could also be applied but in that case the explanatory variables of the models would be reduced drastically. (A significance level above $10 \%$ was always separately indicated.)

\subsection{Hypothesis analysis}

In the study we analysed the variables explaining the evolution of stock exchange rates at three dates:

1) disclosure of the 2017 statement,

2) disclosure of the Q1 2018 report,

3) the whole period between the publication of the 2017 and the Q1 2018 reports. 
We must emphasise again that we did not focus on the parameter estimation of different explanatory variables for modelling. Our objective was to identify the accounting data and data groups that did have a significant effect on market prices. We did not intend to explain the evolution of the rates with the help of actual regression parameters. In the next step of our study, we wanted to find the group of variables where the selected models offered a significant connection.

\section{Table 5}

Findings of the regression analysis for all financial institutions

\begin{tabular}{|c|c|c|c|c|}
\hline Model & $\begin{array}{c}\text { Result } \\
\text { variable }\end{array}$ & $\begin{array}{l}\text { Model sig. } \\
\text { (F-probe) }\end{array}$ & Adjusted R ${ }^{2}$ & $\begin{array}{c}\text { Significant explanatory } \\
\text { variables }\end{array}$ \\
\hline 1 & drPrice_18_17 & 0.104 & 0.043 & $\begin{array}{l}\text { rFVTPL_2017 } \\
\text { rFVTOCI_2017 } \\
\text { rAC_2017 } \\
\text { dAC_201801 }\end{array}$ \\
\hline 2 & drPrice_18q & 0.07 & 0.191 & $\begin{array}{l}\text { rFVTPL_201801 (sig. 0.159) } \\
\text { rFVTPL_2018q1 } \\
\text { dFVTPL_2018q1 } \\
\text { rFVTOCI_2017 } \\
\text { rFVTOCI_201801 } \\
\text { dFVTOCI_201801 (sig. 0.135) } \\
\text { dFVTOCI_2018q1 } \\
\text { rAC_2017 } \\
\text { rAC_201801 } \\
\text { dAC_201801 } \\
\text { rECL_201801 } \\
\text { rECL_2018q1 } \\
\text { dECL_2018q1 }\end{array}$ \\
\hline 3 & drPrice_18q_17 & 0.01 & 0.261 & $\begin{array}{l}\text { lnTotalAssets_2017 (sig. 0.109) } \\
\text { dTotalAssets_201801 } \\
\text { dTotalAssets_2018q1 (sig. 0.247) } \\
\text { rFVTPL_201801 (sig. 0.275) } \\
\text { dFVTPL_2018q1 } \\
\text { rFVTOCI_2017 } \\
\text { rAC_2017 } \\
\text { rAC_201801 } \\
\text { rAC_2018q1 (sig. 0.108) } \\
\text { dAC_201801 (19)_2018q1 } \\
\text { dAC_218qu } \\
\text { rECL_201801 } \\
\text { rECL_2018q1 } \\
\text { dECL_2018q1 }\end{array}$ \\
\hline
\end{tabular}

Source: own design 
As you can see from Table 5, the descriptive statistics of the models quickly improved as time passed. At the disclosure of the 2017 financial statements, there were no significant models at $10 \%$ significance level among financial figures and stock exchange rate changes although the probe was only slightly lower than $10 \%$. At the same time, the explanatory nature of model 1 was the lowest by far and only 4 variables proved to be significant.

As we got on to analyse the effect of the Q1 2018 report, the features of the model improved drastically. Model 2 was significant at $10 \%$ significance level; its explanatory nature was close to $20 \%$. The number of significant explanatory variables also multiplied from 4 to 11 and there were two variables offering a connection slightly above the $10 \%$ significance level.

Model 3 covering the whole quarter year was significant at $1 \%$ significance level, its explanatory nature was over $25 \%$ including 10 significant and 4 non-significant variables. It should be noted this had been the first time when a variable related to the size of a financial institution was among the significant elements.

Accordingly, analysing a later or longer period, the changes in the IFRS 9 standard started to exert an impact on the change of market rates in a growing group and to an increasing extent. We think our results show that market players needed time to "get used to" and to start using the new information for their decisions.

There is, however, another circumstance we have not considered yet. The IFRS regulation allowed financial institutions to choose when they wanted to publish the figures generated subject to the new rules. It could be part of the 2017 statement or a separate document presenting the first application of IFRS 9 or as part of the Q1 2018 report. In the next step, we examined when out of the three options the different financial institutions published their IFRS 9 figures. The findings are summed up in Table 6.

Table 6

Regression analysis of financial institutions having disclosed IFRS 9 figures

\begin{tabular}{clcll}
\hline Model & \multicolumn{1}{c}{$\begin{array}{c}\text { Result } \\
\text { variable }\end{array}$} & $\begin{array}{c}\text { Model sig. } \\
\text { (F-probe) }\end{array}$ & Adjusted $\mathbf{R}^{2}$ & $\begin{array}{c}\text { Significant } \\
\text { explanatory variables }\end{array}$ \\
\hline \multirow{2}{*}{4} & & & dTotalAssets_201801 \\
& $\begin{array}{l}\text { financial } \\
\text { Finstitutions having }\end{array}$ & 0.038 & 0.232 & rIAS39impaim \\
& disclosed IFRS 9 & & rECL_201801 \\
& figures in their & & dECL_201801 \\
& 2017 report & & & \\
\hline
\end{tabular}




\begin{tabular}{|c|c|c|c|c|}
\hline Model & $\begin{array}{c}\text { Result } \\
\text { variable }\end{array}$ & $\begin{array}{l}\text { Model sig. } \\
\text { (F-probe) }\end{array}$ & Adjusted $\mathrm{R}^{2}$ & $\begin{array}{c}\text { Significant } \\
\text { explanatory variables }\end{array}$ \\
\hline 5 & $\begin{array}{l}\text { drPrice_18q } \\
\text { Financial } \\
\text { institutions having } \\
\text { disclosed IFRS } 9 \\
\text { figures in their } \\
2017 \text { report or in } \\
\text { a separate report }\end{array}$ & 0.07 & 0.484 & $\begin{array}{l}\text { rFVTPL_2017 } \\
\text { rFVTPL_2018q1 } \\
\text { dFVTPL_2018q1 } \\
\text { rFVTOCI_201801 } \\
\text { rFVTOCI_2018q1 } \\
\text { dFVTOCI_201801 } \\
\text { (szig. 0,153) } \\
\text { dFVTOCI_2018q1 } \\
\text { rAC_2017 } \\
\text { rAC_2018q1 } \\
\text { dAC_201801 } \\
\text { rIAS39impaim } \\
\text { rECL_2018q1 } \\
\text { dECL_2018q1 }\end{array}$ \\
\hline
\end{tabular}

Source:own design

Model 4 can be taken as a modification of model 1: we analysed the financial institutions already having disclosed their new figures as per IFRS 9 in their 2017 reports. Not surprisingly, the change is obvious. The model is significant at $5 \%$ significance level, its explanatory power is above $20 \%$.

Model 5 can be interpreted as a modification of model 2: we analysed the group of financial institutions already having disclosed their IFRS 9 figures either as part of their 2017 report or in a separate document? ${ }^{3}$. The model was significant at 10\% significance level, its explanatory power was close to $50 \%$, it included 12 significant and 1 non-significant variables. It, however, should be noted that autocorrelation and multi-collinearity naturally present in financial figures may play a part for the high explanatory power. We suppose the results may reflect the appearance of investors' knowledge accumulated over Q1 in the prices.

As we have emphasised repeatedly, our objective was to identify the groups of data connected to the implementation of IFRS 9 exercising an impact on stock exchange rates. Thus, Tables 7 and 8 are summaries of the variables carrying significant connections.

3 Note the analysis was performed for other combinations too, but they did not lead to any results. 
Table 7 is a summary of modelling. Its columns display the models, its rows the whole group of variables. Significant connections are marked with „x”.

Table 7

Detailed results of modelling

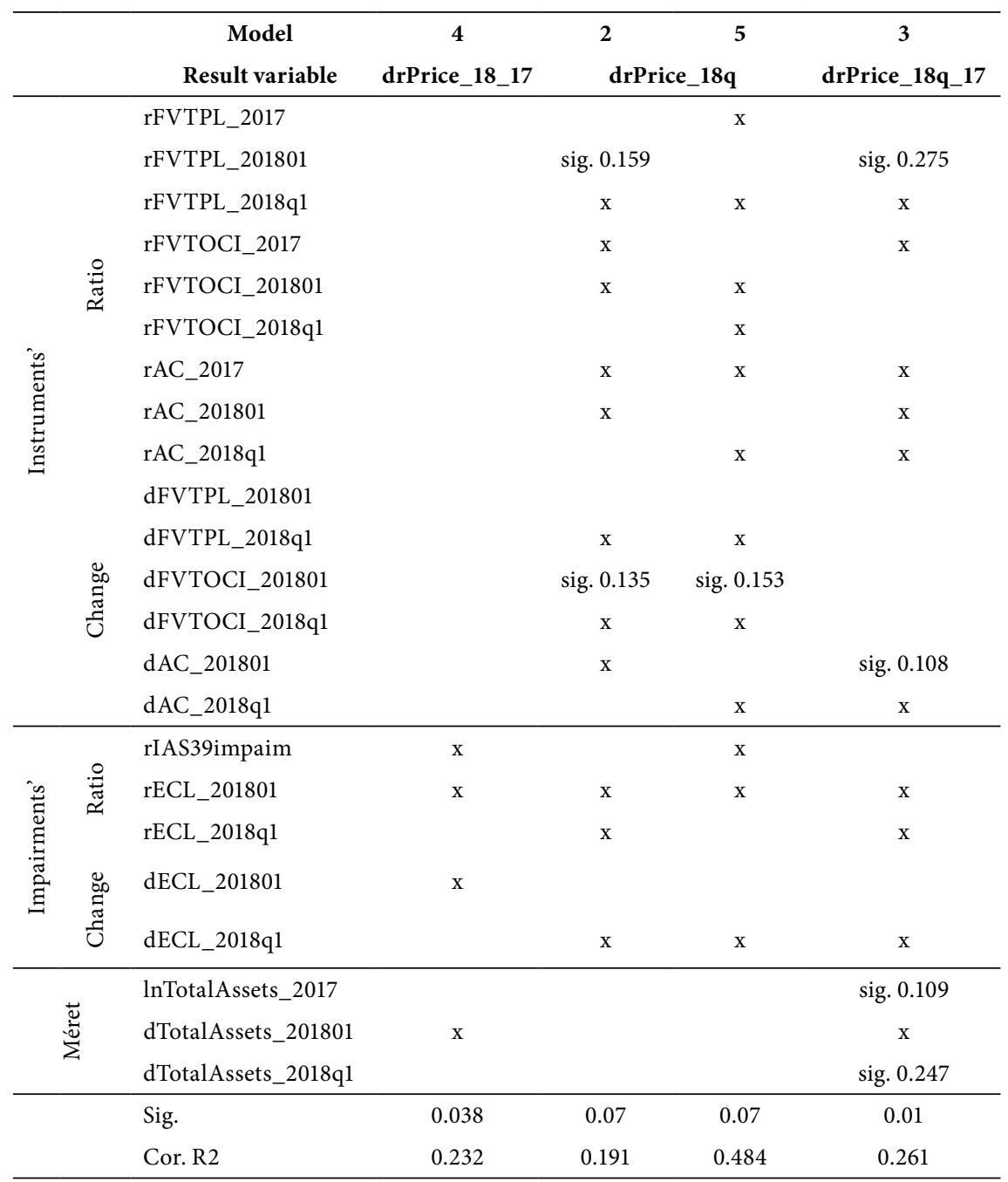

Source: own design

Table 7 in a structure aligned to Figure 3 is a summary of the findings of our regression analysis. It shows that Model 4 alone proved to be meaningful regarding our analysis related to the disclosure of the 2017 report. Model 4 clearly showed 
the new calculation of impairment (ECL) implemented by the IFRS 9 standard and the resulting change in total assets (dTotal Assets) were decisive. We may explain this with the effect of certain financial institutions already providing detailed IFRS 9 figures getting more in the limelight and markets starting to incorporate the new information in the prices, while the majority of financial institutions were not significantly affected.

The other models (Models 2, 3 and 5) are more homogeneous both regarding their explanatory power and the variables involved. We can draw the conclusion that the new type of information was incorporated in the decisions step by step, improving in time and in a higher and higher number of groups.

Finally, Table 8 in a structure aligned to Figure 3 displays the compressed results of modelling. Compression means we counted the significant connections related to a given factor.

Table 8

Compressed results of modelling

\begin{tabular}{|c|c|c|c|c|c|c|c|c|}
\hline \multicolumn{3}{|c|}{$\begin{array}{c}\text { Model } \\
\text { Result variable }\end{array}$} & $\begin{array}{c}4 \\
\text { drPrice_18_17 }\end{array}$ & $\begin{array}{c}2 \\
\text { drPri }\end{array}$ & $\begin{array}{c}5 \\
18 q\end{array}$ & $\begin{array}{c}3 \\
\text { drPrice_18q_17 }\end{array}$ & Total & $\begin{array}{l}\text { Sum } \\
\text { total }\end{array}$ \\
\hline \multirow{6}{*}{ 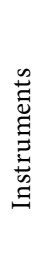 } & \multirow{3}{*}{ 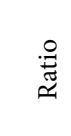 } & FVTPL & & 1 & 2 & 1 & 4 & \multirow{3}{*}{16} \\
\hline & & FVTOCI & & 2 & 2 & 1 & 5 & \\
\hline & & $\mathrm{AC}$ & & 2 & 2 & 3 & 7 & \\
\hline & \multirow{3}{*}{ 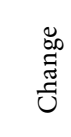 } & FVTPL & & 1 & 1 & & 2 & \\
\hline & & FVTOCI & & 1 & 1 & & 2 & 7 \\
\hline & & $\mathrm{AC}$ & & 1 & 1 & 1 & 3 & \\
\hline \multirow{2}{*}{ 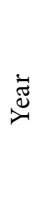 } & 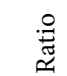 & ECL & 2 & 2 & 2 & 2 & 8 & 8 \\
\hline & 胥 & ECL & 1 & 1 & 1 & 1 & 4 & 4 \\
\hline & $\begin{array}{l}\tilde{N} \\
\text { is }\end{array}$ & $\begin{array}{l}\text { Total- } \\
\text { Assets }\end{array}$ & 1 & & & 1 & 2 & 2 \\
\hline & & Sig. & 0.038 & 0.07 & 0.07 & 0.01 & - & - \\
\hline & & Cor. R2 & 0.232 & 0.191 & 0.484 & 0.261 & - & - \\
\hline
\end{tabular}

Source own design 


\section{CONCLUSIONS}

We can also test our hypotheses with the help of Table 8. We assumed in $\mathrm{H}_{1}$ that the changes in the composition of financial instruments had a material impact on the evolution of stock exchange rates. Our results showed that the change of the composition of financial instruments exerted significant effect only when the Q1 2018 reports were published. It is obvious, however, that the volume of instruments at any time was more influential than their change. Accordingly, we rejected $H_{1}$, because the variables measuring change were only significant in relation to short term exchange fluctuations in Q1 2018 and had no impact on exchange rate changes either at the end of 2017 or in the long run. The findings match the literature studying the importance of the categorisation of financial instruments. Research papers mainly focused on the volume changes appearing as a solution of the 2008 crisis, while in our study, we analysed those correlations in a financially stable period.

In $H_{2}$ we assumed a significant impact of impairment calculation. It is clear from Table 8 that changes in impairment had a significant impact on stock exchange rates in each model. Please note, however, that the actual size of impairment had a significant effect in many more cases than its change. Accordingly, we accept $H_{2}$. The new logic of impairment calculations reiterates the findings of earlier literature (Beaver et al., 1989), i.e. the magnitude of impairment allowance may grant investors a „feeling of security”.

In $\mathrm{H}_{3}$ we assumed a significant impact of changes in balance sheet total. Table 8 illustrated it had the lowest impact on the evolution of exchange rates by far. Accordingly, $\mathrm{H}_{3}$ has been rejected.

In $\mathrm{H}_{4}$ we assumed a significant impact of the date when IFRS 9 information was disclosed. If we compare Models 4 and 5 to each other and to the first three models, it is obvious that a large group of variables connected to the new regulations exerted material impact with institutions that presented their IFRS 9 figures in separate publications rather than as part of their reports. Thus, the explanatory power of our model is the strongest by far. Accordingly, $\mathrm{H}_{4}$ has been accepted.

As a result of our study, we have found investors interpreted the changes stipulated in the new standard positively, since the new categorisation of financial instruments improved the transparency of financial reports. In addition, it simplified assessment and proper impairment allowance in advance suggested prudence on the part of banks. 


\section{APPENDIX}

\section{Impact of the COVID19 pandemic on impairment management}

The health, social and economic effects of the COVID19 pandemic affect the risk management of banks and the related tasks of impairment allowance expressed in the IFRS 9 standard. The European Central Bank (EBC), the European Securities and Markets Authority (ESMA), and the European Banking Authority (EBA) hand-in-hand with the International Accounting Standards Board (IASB) have issued guidelines to allow uniform management of a special situation regarding the IFRS 9 standard. It is widely accepted that banks should apply proper flexibility side by side with prudent consideration regarding impairment allowance.

The first important question is whether the financial-economic situation caused by the pandemic affects the categorisation of financial instruments into the ECL categories identified by IFRS 9. Many households must face financial difficulties as a result of the loss of jobs and economic entities are faced with and must recognise heavy losses due to lost orders. For that reason, several countries including Hungary have implemented measures to defer debt service. In the presence of the repayment or interest payment moratoriums introduced, is it necessary to reclassify receivables in category 1 into category2 for non-payment? The EBC, ESMA, EBA guidelines underline you should not apply the stipulations of the standard mechanically, so non-payment because of moratoriums - whether private or legislative - should not result in automatic reclassification. The guidelines also emphasise that assessment of increased credit risk must be analysed in its complexity. The European Commission stated, „short term support measures aimed to bridge liquidity needs do not automatically lead to stricter accounting or prudential treatment if the financial situation otherwise does not deteriorate". According to EBA, the moratorium identifies new reference dates for calculating borrowers' days in arrears and all that has an impact on the assessment of credit risk due to payment overdue by more than 30 days and on the statement of default for non-performance overdue by more than 90 days.

The guidelines emphasise the part played by credit guarantee in the management of issues caused by the pandemic. Recommendations published by different bodies state if a government or other institution issue a borrower guarantee to secure a given loan, the credit institution involved must take that into account on quantifying the expected credit loss. A guarantee may compensate for future losses, thus reducing impairment allowance by the bank.

The authorities publishing different recommendations call the banks' attention to the importance of providing information. Proper information must be published 
regarding expected losses analysing both optimistic and pessimistic scenarios. In the notes to financial statements the specific accounting principles of evaluation, methods of estimation and decisions adopted under the COVID19 pandemic must be presented. It will allow market players to assess a given credit institution to establish credit risk exposure. Transparency is extremely important in the current situation.

ECB encourages banks to make use of the temporary measures of the IFRS 9 standard linked to the impact of COVID19 allowing impairment allowance on expected loss to be reduced which has a beneficial effect on the capital adequacy ratios of banks. At the introduction of IFRS 9 you could request the relevant authority to grant a 5-year transitional period. ECB, hand-in-hand with the Basel Committee of Banking Supervision, now propose the repeated prolongation of the 5-year temporary period.

\section{Some important recommendations are the following:}

- The opinion of the European Central Bank "amendments to the Union prudential framework in response to the COVID19 pandemic" (CON/2020/16), 20 May 2020.

- Communication from the Commission to the European Parliament and the "Council on the application of the accounting and prudential frameworks to facilitate EU bank lending - Supporting businesses and households amid COVID-19", Brussels, 28.04.2020. COM(2020) 169 final.

- Regulation of the European Parliament and of the Council amending Regulations (EU) No 575/2013 and (EU) 2019/876 as regards adjustments in response to the COVID19 pandemic, Brussels, 28.04.2020 COM(2020) 310 final.

- ESMA "Accounting implications of the COVID-19 outbreak on the calculation of the expected credit losses in accordance with IFRS 9", 25 March 2020.

- CEAOB statement of 25 March 2020: CEAOB emphasises the following areas that are of high importance in view of COVID-19 impact on audits of financial statements.

- IASB statement "IFRS 9 and COVID-19 - Accounting for expected credit losses applying IFRS 9 Financial Instruments in the light of current uncertainty resulting from the COVID-19 pandemic", 27 March 2020.

- $\mathrm{EBH}$ "Statement on the application of the prudential framework regarding Default, Forbearance and IFRS9 in light of COVID-19 measures", 25 March 2020. 


\section{ANNEXES}

Annex 1

\section{Model variables}

\begin{tabular}{|c|c|c|c|c|c|c|}
\hline Name & Variable & Description & Variable & Description & Variable & Description \\
\hline \multirow{3}{*}{ 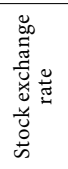 } & \multirow{3}{*}{ Price } & \multirow{3}{*}{$\begin{array}{l}\text { Stock } \\
\text { exchange } \\
\text { rate of given } \\
\text { financial } \\
\text { institution }\end{array}$} & \multirow{3}{*}{ drPrice } & \multirow{3}{*}{$\begin{array}{l}\% \text { change of price } \\
\text { on } 5-5 \text { trading } \\
\text { days preceding } \\
\text { and following } \\
\text { publication of } \\
\text { report }\end{array}$} & drPrice_18_17 & $\begin{array}{l}\text { drPrice linked } \\
\text { to } 2017 \text { report }\end{array}$ \\
\hline & & & & & drPrice_18q & $\begin{array}{l}\text { drPrice linked } \\
\text { to Q1 } 2018 \text { report }\end{array}$ \\
\hline & & & & & drPrice_18q_17 & $\begin{array}{l}\text { drPrice for the whole } \\
\text { period studied }\end{array}$ \\
\hline \multirow{15}{*}{ 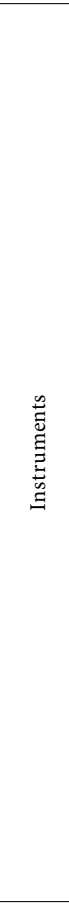 } & \multirow{5}{*}{ FVTPL } & \multirow{5}{*}{$\begin{array}{l}\text { Instrument at } \\
\text { fair value on } \\
\text { profit and loss }\end{array}$} & \multirow{3}{*}{ rFVTPL } & \multirow{3}{*}{$\begin{array}{l}\% \text { of FVTPL to } \\
\text { balance sheet total }\end{array}$} & rFVTPL_2017 & $\begin{array}{l}\text { rFVTPL } \\
\text { as of 31.12.2017 }\end{array}$ \\
\hline & & & & & rFVTPL_201801 & $\begin{array}{l}\text { rFVTPL } \\
\text { as of 01.01.2018 }\end{array}$ \\
\hline & & & & & rFVTPL_2018q1 & $\begin{array}{l}\text { rFVTPL } \\
\text { as of 31.03.2018 } \\
\end{array}$ \\
\hline & & & \multirow{2}{*}{ dFVTPL } & \multirow{2}{*}{$\begin{array}{l}\% \text { change of } \\
\text { FVTPL compared } \\
\text { to previous period }\end{array}$} & dFVTPL_201801 & $\begin{array}{l}\text { FVTPL change } \\
\text { from } 31.12 .2017 \\
\text { to } 01.01 .2018\end{array}$ \\
\hline & & & & & dFVTPL_2018q1 & $\begin{array}{l}\text { FVTPL change } \\
\text { from } 01.01 .2018 \\
\text { to } 31.03 .2018\end{array}$ \\
\hline & \multirow{5}{*}{ FVTOCI } & \multirow{5}{*}{$\begin{array}{l}\text { Instrument at } \\
\text { fair value on } \\
\text { OCI }\end{array}$} & \multirow{3}{*}{ rFVTOCI } & \multirow{3}{*}{$\begin{array}{l}\% \text { of to balance } \\
\text { sheet total }\end{array}$} & rFVTOCI_2017 & $\begin{array}{l}\text { rFVTOCI } \\
\text { as of 31.12.2017 }\end{array}$ \\
\hline & & & & & rFVTOCI_201801 & $\begin{array}{l}\text { rFVTOCI } \\
\text { as of 01.01.2018 }\end{array}$ \\
\hline & & & & & rFVTOCI_2018q1 & \begin{tabular}{|l|} 
rFVTOCI \\
as of 31.03.2018 \\
\end{tabular} \\
\hline & & & \multirow{2}{*}{ dFVTOCI } & \multirow{2}{*}{$\begin{array}{l}\% \text { change } \\
\text { of FVTOCI } \\
\text { compared } \\
\text { to previous period }\end{array}$} & dFVTOCI_201801 & $\begin{array}{l}\text { FVTOCI change } \\
\text { from 31.12.2017 } \\
\text { to } 01.01 .2018\end{array}$ \\
\hline & & & & & dFVTOCI_2018q1 & $\begin{array}{l}\text { FVTOCI change } \\
\text { from 01.01.2018 } \\
\text { to } 31.03 .2018 \\
\end{array}$ \\
\hline & \multirow{5}{*}{$\mathrm{AC}$} & \multirow{5}{*}{$\begin{array}{l}\text { Instrument } \\
\text { at amortised } \\
\text { cost }\end{array}$} & \multirow{3}{*}{$\mathrm{rAC}$} & \multirow{3}{*}{$\begin{array}{l}\% \text { of } \mathrm{AC} \\
\text { to balance sheet } \\
\text { total }\end{array}$} & rAC_2017 & rAC as of 31.12.2017 \\
\hline & & & & & rAC_201801 & rAC as of 01.01.2018 \\
\hline & & & & & rAC_2018q1 & rAC as of 31.03 .2018 \\
\hline & & & \multirow{2}{*}{$\mathrm{dAC}$} & \multirow{2}{*}{$\begin{array}{l}\% \text { change of AC } \\
\text { compared } \\
\text { to previous period }\end{array}$} & dAC_201801 & \begin{tabular}{|l|} 
AC change \\
from 31.12.2017 \\
to 01.01 .2018 \\
\end{tabular} \\
\hline & & & & & dAC_2018q1 & \begin{tabular}{|l|} 
AC change \\
from 01.01.2018 \\
to 31.03.2018 \\
\end{tabular} \\
\hline \multirow{5}{*}{ 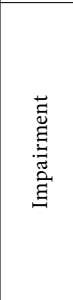 } & IAS39imp & \begin{tabular}{|l|}
$\begin{array}{l}\text { Impairment } \\
\text { by IAS } 39 \\
\text { (old standard) }\end{array}$ \\
\end{tabular} & rIAS39imp & $\begin{array}{l}\% \text { of IAS39Imp to } \\
\text { balance sheet total }\end{array}$ & \multicolumn{2}{|c|}{ As of 31.12.2017. } \\
\hline & \multirow{4}{*}{ ECL } & \multirow{4}{*}{$\begin{array}{l}\text { Impairment } \\
\text { by IFRS 9 } \\
\text { (new stan- } \\
\text { dard) }\end{array}$} & \multirow{2}{*}{ rECL } & \multirow{2}{*}{$\begin{array}{l}\% \text { of ECL to } \\
\text { balance sheet total }\end{array}$} & rECL_201801 & rECL as of 01.01.2018 \\
\hline & & & & & rECL_2018q1 & rECL as of 31.03 .2018 \\
\hline & & & & $\%$ change of ECL & dECL_201801 & \begin{tabular}{|l|} 
ECL change \\
from 31.12.2017 \\
to 01.01.2018 \\
\end{tabular} \\
\hline & & & dECL & $\begin{array}{l}\text { compared to } \\
\text { previous period }\end{array}$ & dECL_2018q1 & \begin{tabular}{|l|} 
ECL change \\
from 01.01.2018 \\
to 31.03.2018 \\
\end{tabular} \\
\hline \multirow{3}{*}{ : } & \multirow{3}{*}{$\begin{array}{l}\text { Total } \\
\text { Assets }\end{array}$} & & $\ln$ TotalAssets & $\begin{array}{l}\text { Natural } \\
\text { logarythm } \\
\text { of balance sheet } \\
\text { total }\end{array}$ & InTotalAssets_2017 & $\begin{array}{l}\ln \text { TotalAssets } \\
\text { as of 31.12.2017 }\end{array}$ \\
\hline & & $\begin{array}{l}\text { Balance Sheet } \\
\text { Total }\end{array}$ & & $\%$ change & dTotalAssets_201801 & $\begin{array}{l}\text { dTotalAssets change } \\
\text { from } 31.12 .2017 \\
\text { to } 01.01 .2018\end{array}$ \\
\hline & & & dTotalAssets & $\begin{array}{l}\text { of balance } \\
\text { sheet otal }\end{array}$ & dTotalAssets_2018q1 & $\begin{array}{l}\text { dTotalAssets change } \\
\text { from } 01.01 .2018 \\
\text { to } 31,03,2018 \\
\end{array}$ \\
\hline
\end{tabular}




\section{Annex 2}

\section{Descriptive statistics of variables}

\begin{tabular}{|l|c|c|c|c|c|}
\hline \multicolumn{1}{|c|}{ Variable } & Average & Median & Variance & Minimum & Maximum \\
\hline drPrice_18_17 & 0.9871 & 0.9943 & 0.0010 & 0.8700 & 1.0500 \\
\hline drPrice_18q & 0.9928 & 0.9994 & 0.0010 & 0.8600 & 1.0900 \\
\hline drPrice_18q_17 & 0.9688 & 0.9890 & 0.0140 & 0.5100 & 1.3700 \\
\hline rFVTPL_2017 & 0.1087 & 0.0427 & 0.0190 & 0.0000 & 0.7400 \\
\hline rFVTPL_201801 & 0.1127 & 0.0505 & 0.0190 & 0.0000 & 0.7400 \\
\hline rFVTPL_2018q1 & 0.1091 & 0.0385 & 0.0190 & 0.0000 & 0.7300 \\
\hline dFVTPL_201801 & 2.5807 & 1.0068 & 74.8020 & 0.1200 & 76.4400 \\
\hline dFVTPL_2018q1 & 0.9799 & 0.9891 & 0.3580 & 0.0000 & 4.0700 \\
\hline rFVTOCI_2017 & 0.0996 & 0.0891 & 0.0050 & 0.0000 & 0.3300 \\
\hline rFVTOCI_201801 & 0.0889 & 0.0806 & 0.0040 & 0.0000 & 0.2800 \\
\hline rFVTOCI_2018q1 & 0.0888 & 0.0796 & 0.0040 & 0.0000 & 0.3300 \\
\hline dFVTOCI_201801 & 0.9611 & 0.9899 & 0.3040 & 0.0000 & 4.1100 \\
\hline dFVTOCI_2018q1 & 1.5107 & 0.9865 & 14.8620 & 0.0000 & 36.2100 \\
\hline rAC_2017 & 0.7181 & 0.7524 & 0.0250 & 0.2300 & 1.0000 \\
\hline rAC_201801 & 0.7231 & 0.7583 & 0.0240 & 0.1400 & 0.9700 \\
\hline rAC_2018q1 & 0.7243 & 0.7562 & 0.0240 & 0.1100 & 0.9600 \\
\hline dAC_201801 & 1.0125 & 0.9996 & 0.0120 & 0.5900 & 1.4500 \\
\hline dAC_2018q1 & 1.0072 & 1.0027 & 0.0050 & 0.6700 & 1.2100 \\
\hline rECL_201801 & 0.0306 & 0.0148 & 0.0020 & 0.0000 & 0.2400 \\
\hline rECL_2018q1 & 0.0324 & 0.0166 & 0.0020 & 0.0000 & 0.2600 \\
\hline dECL_201801 & 1.1083 & 1.0820 & 0.0710 & 0.1500 & 2.6000 \\
\hline dECL_2018q1 & 1.1059 & 0.9825 & 0.7320 & 0.0100 & 7.4100 \\
\hline lnTotalAssets_2017 & 11.2900 & 11.1752 & 3.2430 & 7.4800 & 14.7400 \\
\hline dTotalAssets_201801 & 1.0000 & 0.9993 & 0.0010 & 0.8700 & 1.2100 \\
\hline dTotalAssets_2018q1 & 1.0067 & 0.9994 & 0.0030 & 0.7800 & 1.1800 \\
\hline
\end{tabular}




\section{REFERENCES}

Ahmed, A. S. - Takeda, C. -Thomas, S. (1999): Bank loan loss provisions: a re-examination of capital management, earnings management and signaling effects. Journal of Accounting and Economics 28, 1-26.

Beatty, A. - Liao, S. (2011): Do delays in expected loss recognition affect banks' willingness to lend? https://doi.org/10.1016/j.jacceco.2011.02.002.

Beaver, W. H. - Eger, C. -Ryan, S. - Wolfson, M. (1989): Financial reporting, supplemental disclosures, and bank share prices. Journal of Accounting Research 27(2), 157-178.

Cantrell, B. W. - McInnis, J. M. - Yust, C. G. (2014): Predicting Credit Losses: Loan Fair Values versus Historical Costs. The Accounting Review 89(1), January, 147-176.

Covas, F. - Nelson, W. (2018): Current Expected Credit Loss: Lessons from 2007-2009. Staff Working Paper 2018-1. Bank Policy Institute.

EL Sood, H. A. (2012): Loan loss provisioning and income smoothing in US banks pre and post the financial crisis. International Review of Financial Analysis 25, December, 64-72.

Fiechter, P. (2011): The Effects of the Fair Value Option under IAS 39 on the Volatility of Bank Earnings. Journal of International Accounting Research 10(1), Spring, 85-108.

Fiechter, P. (2011): Reclassification of Financial Assets under IAS 39: Impact on European Banks' Financial Statements. Accounting in Europe 8(1), 49-67.

Gebhardt, G. - Novotny-Farkas, Z. (2011): Mandatory IFRS Adoption and Accounting Quality of European Banks. Journal of Business Finance and Accounting 38(3-4).

Georgiou, O. - JaCK, L. (2011): In pursuit of legitimacy: a history behind fair value accounting. The British Accounting Review 43(1), 311-323.

IAS 39 Financial Instruments: Recognition and Measurement. London: www.ifrs.org.

IFRS 9 Financial Instruments, London; www.ifrs.org.

Kund, A. G. - Rugilo, D. (2018): Does IFRS 9 increase Financial Stability? SSRN Electronic Journal, https://papers.ssrn.com/sol $3 /$ papers.cfm?abstract_id=3282509.

LAUx, C. (2012): Financial Instruments, Financial Reporting, and Financial Stability. Accounting and Business Research 42(3), 1-22.

LAux, C. - LEuz, C., (2010): Did fair-value accounting contribute to the financial crisis? Journal of Economic Perspectives 24(1), 93-118.

Lu, Y. - Nikolaev, V. (2019): Expected Loan Loss Provisioning: An Empirical Model. Chicago Booth Research Paper No. 19-11.

O'HANLON, J. (2013): Did loan-loss provisioning by UKbanks become less timely after implementation of IAS 39 ? Accounting and Business Research 43(1), 1-34.

Onali, E. - Ginesti, G. (2014): Pre-adoption market reaction to IFRS 9: A cross-country eventstudy. Journal of Accounting and Public Policy 33 (6).

Onali, E. - Ginesti, G. (2015): New Accounting Rules for Loan Loss Provisions in Europe: Much Ado about Nothing? MPRA Paper No. 64266, posted 12 May.

OzILI, P. K. (2019): Impact of IAS 39 reclassification on Income Smoothing by European Banks. University Library of Munich (Germany): MPRA Paper 92098.

PaAnanen, M. - Renders, A. - Shima, K. M. (2012): The amendment of IAS 39: Determinants of reclassification behaviour and capital market consequences. Journal of Accounting, Auditing \& Finance, 27(2), 208-235, https://doi.org/10.1177/0148558X11409151.

Wheeler, BArrett (2019) Unrecognized Expected Credit Losses and Bank Share Prices (January 22). Available at SSRN: https://ssrn.com/abstract=3051473.

ZHAN, Y. (2013): The effect of reclassification under amendment to IAS 39 on liquidity of bank stocks in the EU. Tilburg University (Germany), http://arno.uvt.nl/show.cgi?fid=129305. 